\title{
LONG TERM FOLLOW-UP OF NEOADJUVANT-ADJUVANT COMBINATION TREATMENT OF IIIA STAGE NON-SMALL-CELL-LUNG CANCER: RESULTS OF NEOADJUVANT CARBOPLATIN/VINORELBINE AND CARBOPLATIN/PACLITAXEL REGIMENS COMBINED WITH SELECTIVE ADJUVANT CHEMOTHERAPY ACCORDING TO IN-VITRO CHEMORESISTANCE TEST.
}

\author{
Vitezslav Kolek ${ }^{\mathrm{a} *}$, Ivona Grygarkova ${ }^{\mathrm{a}}$, Marian Hajduch ${ }^{\mathrm{b}}$, Jiri Klein ${ }^{\mathrm{c}}$, Karol Cwiertka ${ }^{\mathrm{d}}$, \\ Cestmir Neoralc, Katerina Langova ${ }^{\mathrm{e}}$, Vladimir Mihal ${ }^{\mathrm{b}}$
}

\author{
a Departments of Respiratory Medicine, University Hospital, Olomouc, Czech Republic \\ ${ }^{b}$ Department of Experimental Medicine, University Hospital, Olomouc \\ Department of Surgery, University Hospital, Olomouc \\ d Department of Oncology, University Hospital, Olomouc \\ e Department of Biostatistics, University Hospital, Olomouc \\ e-mail:vitezslav.kolek@fnol.cz
}

Received: November 15, 2008; Accepted: November 21, 2008

Key words: Non-small-cell lung cancer/Neoadjuvant chemotherapy/Adjuvant Chemotherapy/In vitro chemoresistance test

Aim: A prospective study investigated survival of patients with stage IIIA non-small-cell-lung cancer (NSCLC) treated with a combination of neoadjuvant and adjuvant chemotherapy.

Methods: Consecutive chemo-naive patients with potentially operable stage IIIA NSCLC received carboplatin-based neoadjuvant treatment. Tumor cells harvested during surgery underwent methylthiazolyl tetrazolium blue (MTT) cytotoxic assay. After surgery, adjuvant chemotherapy was selected, where possible, according to MTT results.

Results: A total of 65 patients were evaluated (31 received carboplatin/vinorelbine, 34 carboplatin/paclitaxel). The overall response rate was $67.7 \%$ (95\% confidence interval [CI]: 56.3-79.1\%) with downstaging in 52.3\% (95\% CI: 40.2-64.5\%) and no significant differences between regimens. Median follow-up was 86 months: median overall survival (OS) was 32.1 months (95\% CI: 7.4-46.5), median time to progression was 25.1 months (95\% CI: 15.1-34.9 months) and five-year overall survival was $35.7 \%$ (95\% CI: 23.7-47.7 \%). Forty-seven patients (72.3 \%) underwent surgery and 43 patients received adjuvant chemotherapy. Five-year survival after tumor resection was $49.5 \%$ (95\% CI: 34.2-64.8\%), median OS was 59.0 months (95\% CI: 34.2-83.1) and median disease free survival after surgery was 57.3 months (95\% CI: 29.5-84.4). With MTT-directed therapy, median OS was 85.1 months (95\% CI: 15.4-148.6) and the 5-year survival rate was $57.0 \%$ (95\% CI: 34.5-79.5\%); the trend for longer survival failed to reach statistical significance.

Conclusions: A combination of carboplatin-based neoadjuvant chemotherapy, surgical resection and adjuvant chemotherapy achieved satisfactory survival rates in stage IIIA NSCLC, especially in patients with complete resection of tumor and those given MTT-directed adjuvant treatment. Our results suggest MTT testing may help optimise adjuvant chemotherapy.

\section{INTRODUCTION}

Lung cancer has an unfavorable prognosis and remains the leading cause of cancer death worldwide. Surgery is the preferred curative method in non-small-cell lung cancer (NSCLC), which represents $75 \%$ of all lung cancer cases, but only early-detected disease can be treated successfully. Optimal treatment of patients with locally advanced NSCLC in stage IIIA is still a matter of discussion, as 5-year survival in these patients varies from $5 \%$ to $15 \%$ and, even after complete resection, can only reach slightly more than $20 \%$ (ref. $^{1,2}$ ). Micrometastases at distant sites are present in almost $80 \%$ of patients with stage IIIA NSCLC $\left(\right.$ ref. $^{3}$ ). Detection by molecular techniques shows the early spread of tumor cells to lymph nodes, whilst the presence of malignant cells in peripheral blood is probably the major cause of early death after complete resection ${ }^{4,5}$. For these reasons, combined treatment modalities are preferred over surgery alone ${ }^{6}$. There are several recommended approaches advocating neoadjuvant or adjuvant chemotherapies combined with surgery ${ }^{7-9}$. Multimodal therapy may also involve neoadjuvant chemoradiotherapy with surgery or radical chemoradiotherapy without surgery ${ }^{10-13}$. The results of the above mentioned therapeutic modalities are influenced by patients' performance status and comorbidities, lymph node involvement, staging accuracy, achievement of downstaging and the type of resection ${ }^{14-18}$.

Chemotherapy after surgery has been studied in several neoadjuvant Phase III studies investigating second 
generation cytotoxic drugs, as well ${ }^{6,7,19}$. This was considered perioperative chemotherapy, with the same drugs administered before and after surgery, and the effects of the postoperative part of the chemotherapy were not systematically evaluated.

In the present study, vinorelbine/carboplatin and paclitaxel/carboplatin doublets were used in the neoadjuvant protocol for IIIA NSCLC, followed by surgery and adjuvant chemotherapy selected according to the results of an in vitro test of chemoresistance. The neoadjuvant regimens were chosen because they are effective in first line NSCLC management and have potentially less toxicity and better tolerability than cisplatin combinations ${ }^{20,21}$. The primary objective of this prospective trial was to assess survival parameters. The secondary end points were the effectiveness and tolerability of chemotherapy and the potential clinical value of in vitro chemoresistance analysis for guiding adjuvant chemotherapy.

\section{MATERIALS AND METHODS}

\section{Study Population}

Chemonaive patients with potentially operable stage IIIA NSCLC were included in a prospective study. The patients were physically examined by a pneumologist, oncologist and thoracic surgeon in order to confirm the stage of disease and confirm the indication for medical and surgical procedures. The tumor was verified by cytology or histology. The staging was performed by chest radiography, computed tomography (CT) scans of the chest and upper abdomen, bronchoscopy with fine needle transbronchial needle aspiration (TBNA) and bone scintigraphy for every patient. Mediastinoscopy and brain CT were optional. The eligibility criteria included age 18 to 75 years, WHO performance status 0 and 1, pulmonary function tests compatible with potential resection, acceptable blood count, serum electrolytes, urea, creatinine, liver enzymes, bilirubin and renal function test. Exclusion criteria were prior malignancy, coexisting serious nonstabilized disease, pregnancy, peripheral neuropathy, a history of psychiatric disorder, drug or alcohol abuse, or active uncontrolled infection. The study was approved by the Institutional Review Boards of the participating institutions and informed consent was obtained from all patients.

\section{Trial Design and Treatment Plan}

Consecutive eligible patients were included from January 1997 to December 2004. Patients received three cycles of inductive chemotherapy (each planned for 21 days): randomly receiving vinorelbine $30 \mathrm{mg} / \mathrm{m}^{2}$ administered as a 10 minute infusion on days 1 and 8 or paclitaxel $200 \mathrm{mg} / \mathrm{m}^{2}$ given as a 3 hour infusion on day 1 , both with carboplatin in a dose of area under the curve (AUC) 6 administered in a 30 minute infusion. Toxicity was assessed using the standard World Health Organization (WHO) criteria $^{22}$.

Surgery was indicated after re-staging consisting of chest radiography, CT, bronchoscopy with TBNA, bone scintigraphy and laboratory tests. Tissue from the tumor was harvested and the methylthiazolyl tetrazolium blue (MTT) cytotoxic assay ${ }^{23}$ was used to determine the in vitro drug chemoresistance of the tumor cells to cisplatin, carboplatin, paclitaxel, docetaxel, vinorelbine, gemcitabine and etoposide.

Three cycles of adjuvant chemotherapy were planned (21 days each). When an indicative result was obtained from the MTT assay, optimal cytotoxic drugs were selected in accordance with the results of the MTT assay. The test could not be used in patients with complete remissions, in cases of only a small number of vital tumor cells isolated, due to microbial contamination or when the cultivated tumor cells were resistant to all drugs tested. Under these conditions, two different drugs from the previous neoadjuvant treatment were chosen. Patients with progression after neoadjuvant chemotherapy were treated with second line chemotherapy, or chemoradiotherapy.

\section{In vitro Chemoresistance Analysis}

Isolated tumor cells were exposed to six concentrations of each drug in duplicate for three days ${ }^{23}$. The yellow tetrazolium salt MTT was reduced to dark blue formazan by viable cells only. Formazan crystals were dissolved in $100 \mu 10 \%$ sodium dodecylsulphate/water $(\mathrm{pH}=5.0)$ overnight at $37{ }^{\circ} \mathrm{C}$. The optical density (OD) was measured at $540 \mathrm{~nm}$ with a microplate reader. The tumor cell survival (TCS) was calculated using the following formula: $\mathrm{TCS}=\left(\mathrm{OD}_{\text {drug exposed well }} /\right.$ mean $\left.\mathrm{OD}_{\text {control wells }}\right) \times 100 \%$. The TCS50 value, the drug concentration lethal to $50 \%$ of the tumor cells, was calculated from the resultant dose response curves. Tumor samples with a drug TCS50 value below the median TCSC50 of lung cancers were evaluated as drug sensitive. Chemicals were obtained from Sigma Chemical Co., USA.

\section{Clinical Evaluation}

During chemotherapy, physical examination, blood counts and biochemistry were performed every 14 days. After adjuvant chemotherapy, clinical check ups and CT were carried out every 3 months for 2 years. Follow-up after the end of chemotherapy (physical examinations, laboratory tests and CT) was conducted every 6 months until death or any point when clinical symptoms had substantially changed. The end date for the survival analysis was 30 June 2007. Response to chemotherapy was evaluated by WHO criteria ${ }^{22}$, with a complete pathologic response defined as $>95 \%$ necrosis and fibrosis. Assessment of mediastinal lymph nodes was performed using the fifths revision of TNM classification ${ }^{1}$.

\section{Statistical Analysis}

Effectiveness and tolerability of neoadjuvant and adjuvant chemotherapy, resectability and survival parameters of patients were evaluated. The data were statistically evaluated for the total series of patients and separately for each neoadjuvant regimen, as well as for patients treated according to the results of MTT assay in comparison to samples where results of in vitro chemoresistance test could not be used. Time to progression (TTP) was cal- 
culated in all subjects from diagnosis to progression or recurrence, disease free survival (DFS) was calculated in those with complete resection from the date of resection to the date of recurrence or death from NSCLC. The median overall survival (OS), TPP and DFS of the total series and the subgroups were calculated using KaplanMeier estimates and the log-rank test; differences between subgroups were evaluated by the $\chi^{2}$ test for categorical variables or by Fisher's exact test ${ }^{24,25}$. Statistical software SPSS v.14 (SPSS Inc., Chicago, USA) was used, level of significance was $\alpha=0.05$.

\section{RESULTS}

\section{Patient Characteristics}

Sixty eight consecutive patients with stage IIIA NSCLC were included and 65 were evaluated ( 3 patients declined from the staging procedures); 54 (83.1\%) were men and $11(16.9 \%)$ were women. The mean age was 59.1 years (range 41-75); in men, 60.3 years; in women, 56.4 years. The clinical characteristics of the total series and subgroups treated with vinorelbine/carboplatin or paclitaxel/carboplatin are shown in Table 1. There were no significant differences between subgroups in TNM classification, histological types, performance status or sex ratio.

\section{Neoadjuvant Chemotherapy}

In total, 65 patients received 194 cycles (92 cycles in the vinorelbine/carboplatin subgroup and 102 cycles in the paclitaxel/carboplatin subgroup). Chemotherapy was postponed in 18 cycles $(9.3 \%)$ due to neutropenia or thrombocytopenia. The dose was reduced in three cycles ( $1.5 \%$ ) due to neutropenic fever. Overall grade 3 toxicity appeared in 27 cycles (13.9\%); toxicity was similar in both subgroups with a predominance of neutropenia - grade 4 in six cycles (3.1\%). Thrombocytopenia grade 3 appeared in two patients $(2.1 \%)$ in the vinorelbine subgroup; whilst myalgia and arthralgia grade 3 were observed in four patients $(4.0 \%)$ in the paclitaxel subgroup.

After chemotherapy, downstaging according to nonsurgical methods was achieved in 34 patients $(52.3 \%)$, and tumor size reduction in 10 patients $(15.4 \%$ ) (Table 2$)$. Surgery was performed in 47 patients $(72.3 \%)$, with complete resection achieved in 44 patients $(67.7 \%)$ (Table 3 ). Early death was noted in two patients. No statistically significant differences were found between the subgroups treated with vinorelbine/carboplatin or paclitaxel/carboplatin.

\section{Survival}

As of the end of June 2007, the median follow-up was 86 months and 44 patients $(67.7 \%)$ had died. The median of OS was 32.1 months, as shown in survival curve (Fig.1). Local progression occurred in 4 patients and distant metastases in 12 patients (brain in 7 patients, lung in 2 patients, liver, supra-adrenal gland and peripheral lymph nodes in one patient each); five patients had both

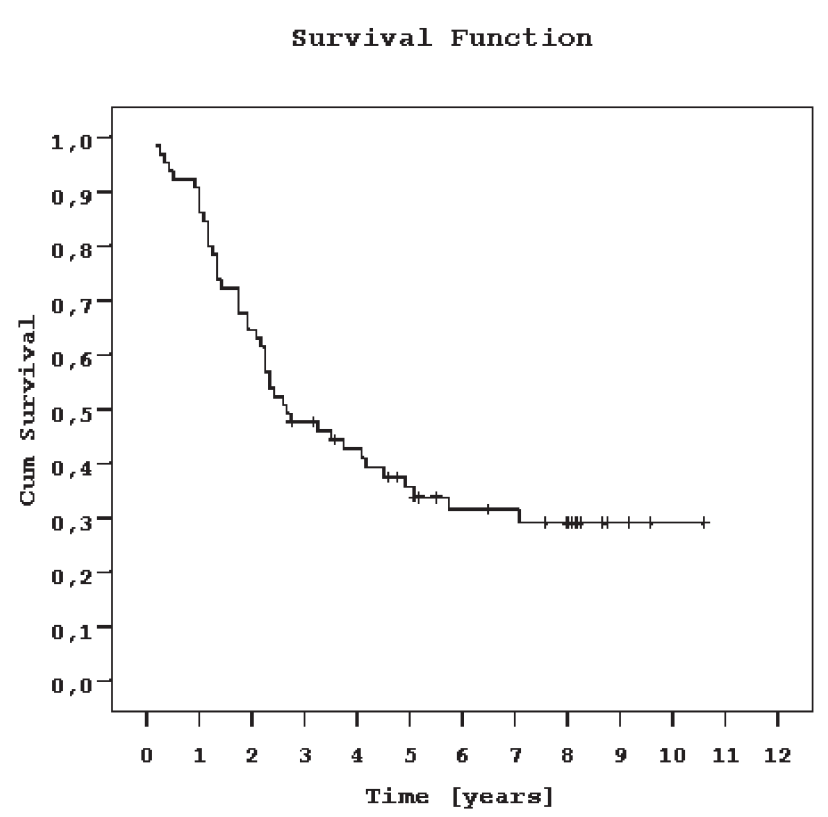

Fig. 1. Overall survival of patients

Survival Functions

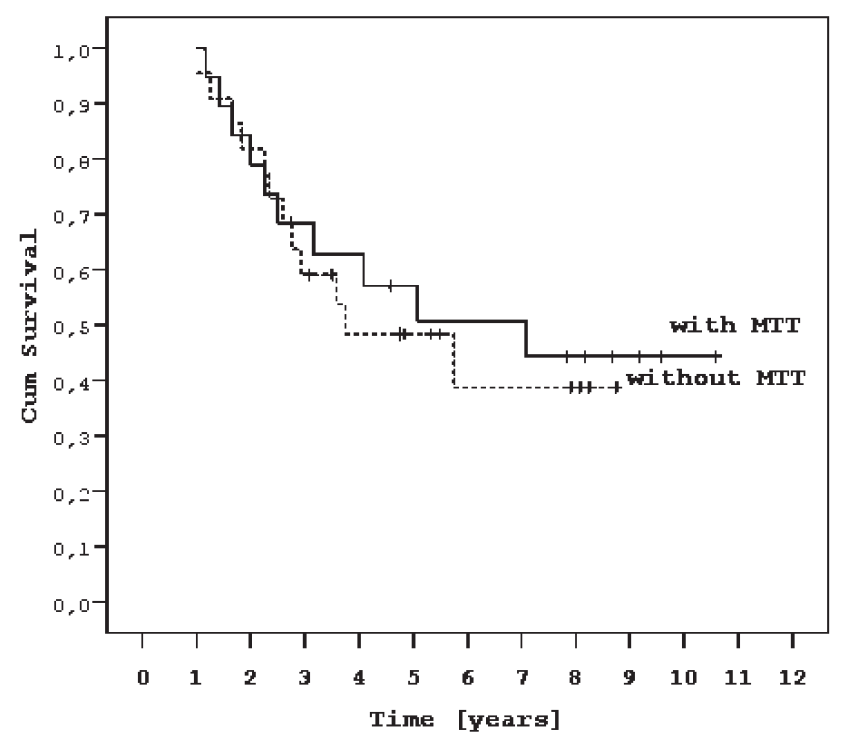

Fig. 2. Survival of patients according to clinical utilization of MTT testing

types of progression. The differences between the vinorelbine/carboplatin and paclitaxel/carboplatin subgroups were not statistically significant for any of the survival parameters (Table 4).

\section{Adjuvant chemotherapy and chemoresistance analysis}

Adjuvant chemotherapy was administered to 43 of the 47 patients receiving surgery with a total of 129 cycles of chemotherapy. It was not applied in two patients of early death and in two patients with significant deterioration of PS. Combinations with cisplatin were used in 21 patients, whilst doublets with carboplatin were chosen in 16 patients. Platinum was combined with vinorelbine 
Table 1. Characteristics of Patients with Stage IIIA NSCLC

\begin{tabular}{|c|c|c|c|c|c|}
\hline \multicolumn{2}{|l|}{ Variables } & $\begin{array}{c}\text { All patients } \\
(\%)\end{array}$ & $\begin{array}{c}\text { Vin/CBDCA } \\
(\%)\end{array}$ & $\begin{array}{c}\mathrm{Pac} / \mathrm{CBDCA} \\
(\%)\end{array}$ & $\mathrm{p}$ Value \\
\hline \multicolumn{2}{|l|}{ Patients } & $65(100)$ & $31(100)$ & $34(100)$ & \\
\hline \multirow[t]{2}{*}{ Gender } & Male & $54(83.1)$ & $28(90.3)$ & $26(76.5)$ & 0.247 \\
\hline & Female & $11(16.9)$ & $3(9.7)$ & $8(23.5)$ & \\
\hline \multicolumn{2}{|c|}{ Performance status (WHO) 0} & $47(72.2)$ & $21(67.7)$ & $26(76.5)$ & 0.432 \\
\hline \multicolumn{2}{|r|}{1} & $18(27.8)$ & $10(32.3)$ & $8(23.5)$ & \\
\hline \multirow[t]{3}{*}{ Stage } & $\mathrm{T} 2 \mathrm{~N} 2 \mathrm{M} 0$ & $45(69.2)$ & $20(64.5)$ & $25(73.5)$ & 0.143 \\
\hline & T3N1M0 & $5(7.7)$ & $1(3.2)$ & $4(11.8)$ & \\
\hline & $\mathrm{T} 3 \mathrm{~N} 2 \mathrm{M} 0$ & $15(23.1)$ & $10(32.3)$ & $5(14.7)$ & \\
\hline \multirow[t]{2}{*}{ Histology } & Squamous cell carcinoma & $44(67.6)$ & $23(74.2)$ & $21(61.8)$ & 0.515 \\
\hline & Adenocarcinoma & $12(18.4)$ & $5(16.1)$ & $7(20.6)$ & \\
\hline \multicolumn{2}{|c|}{ Large cell/non-differentiated carcinoma } & $9(13.8)$ & $3(9.7)$ & $6(17.6)$ & \\
\hline
\end{tabular}

Vin: vinorelbine; CBDCA: carboplatin; Pac: paclitaxel.

Table 2. Effectiveness of Neoadjuvant Chemotherapy (Restaging)

\begin{tabular}{|l|c|c|c|c|c|c|c|}
\hline \multicolumn{1}{|c|}{ Restaging } & All patients & $95 \%$ CI & Vin/CBDCA & $95 \%$ CI & Pac/CBDCA & 95\% CI & p Value \\
\hline Downstaging & $34(52.3 \%)$ & $40.2-64.5$ & $16(51.6 \%)$ & $39.5-63.8$ & $18(52.9 \%)$ & $40.8-65.1$ & 0.980 \\
\hline Size reduction & $10(15.4 \%)$ & $6.6-24.2$ & $5(16.1 \%)$ & $7.2-25.1$ & $5(14.7 \%)$ & $6.1-23.3$ & \\
\hline Stable disease & $5(7.7 \%)$ & $1.2-14.2$ & $2(6.5 \%)$ & $0.5-12.4$ & $3(8.8 \%)$ & $1.9-15.7$ & \\
\hline Progression & $16(24.6 \%)$ & $14.1-35.1$ & $8(25.8 \%)$ & $15.2-36.4$ & $8(23.5 \%)$ & $13.2-33.8$ & \\
\hline ORR & $44(67.7 \%)$ & $56.3-79.1$ & $21(57.7 \%)$ & $56.4-79.1$ & $23(67.6 \%)$ & $56.3-79.0$ & 0.993 \\
\hline Stage I & $24(36.9 \%)$ & & $11(35.5 \%)$ & & $13(38.3 \%)$ & & 0.838 \\
\hline Stage II & $10(15.4 \%)$ & & $5(16.1 \%)$ & & $5(14.7 \%)$ & & \\
\hline Stage IIIA & $15(23.1 \%)$ & & $7(22.6 \%)$ & & $8(23.5 \%)$ & & \\
\hline Stage IIIB & $4(6.2 \%)$ & & $3(9.7 \%)$ & & $1(2.9 \%)$ & & \\
\hline Stage IV & $12(18.5 \%)$ & & $5(16.1 \%)$ & & $7(20.6 \%)$ & & \\
\hline
\end{tabular}

Vin: vinorelbine; CBDCA: carboplatin; Pac: paclitaxel.

Table 3. Surgical Procedures Used After Neoadjuvant Chemotherapy

\begin{tabular}{|l|c|c|c|c|c|c|c|}
\hline \multicolumn{1}{|c|}{ Surgery } & All patients & $95 \% \mathrm{CI}$ & $\begin{array}{c}\text { Vin/ } \\
\text { CBDCA }\end{array}$ & 95\% CI & $\begin{array}{c}\text { Pac/ } \\
\text { CBDCA }\end{array}$ & 95\% CI & p Values \\
\hline All operations & $47(72.3 \%)$ & $61.4-83.2$ & $21(67.7 \%)$ & $56.4-79.1$ & $26(76.5 \%)$ & $66.2-86.8$ & 0.432 \\
\hline Complete resection & $44(67.7 \%)$ & $56.3-79.1$ & $21(67.7 \%)$ & $56.4-79.1$ & $23(67.6 \%)$ & $56.3-79.0$ & 0.993 \\
\hline Pneumonectomy & $21(44.7 \%)$ & $30.5-58.9$ & $10(47.6 \%)$ & $26.3-69.0$ & $11(42.3 \%)$ & $23.3-61.3$ & 0.877 \\
\hline Bilobectomy & $8(17.0 \%)$ & $6.3-27.8$ & $3(14.3 \%)$ & $0.0-29.3$ & $5(19.2 \%)$ & $4.1-34.4$ & \\
\hline Lobectomy & $17(36.2 \%)$ & $22.4-49.9$ & $8(38.1 \%)$ & $17.3-58.9$ & $9(34.6 \%)$ & $16.3-52.9$ & \\
\hline
\end{tabular}

Vin: vinorelbine; CBDCA: carboplatin; Pac: paclitaxel. 
Results of neoadjuvant carboplatin/vinorelbine and carboplatin/paclitaxel regimens...

Table 4. Parameters of Survival

\begin{tabular}{|c|c|c|c|c|c|c|c|}
\hline Survival parameters & $\begin{array}{l}\text { All pa- } \\
\text { tients }\end{array}$ & $95 \% \mathrm{CI}$ & $\begin{array}{c}\text { Vin/ } \\
\text { CBDCA }\end{array}$ & $95 \% \mathrm{CI}$ & $\begin{array}{c}\mathrm{Pac} / \\
\text { CBDCA }\end{array}$ & $95 \% \mathrm{CI}$ & $\mathrm{p}$ Value \\
\hline \multicolumn{8}{|c|}{ Total series } \\
\hline 3 -year survival & $47.0 \%$ & $34.8-59.2$ & $49.2 \%$ & $31.5-67.9$ & $46.1 \%$ & $29.2-63.0$ & 0.923 \\
\hline 5-year survival & $35.7 \%$ & $23.7-47.7$ & $30.4 \%$ & $12.6-48.2$ & $41.2 \%$ & $24.7-57.7$ & 0.955 \\
\hline TTP (months) & $25.1 \mathrm{~m}$ & $15.1-34.9$ & $17.3 \mathrm{~m}$ & $3.9-30.1$ & $25.8 \mathrm{~m}$ & $1.1-56.0$ & 0.431 \\
\hline Median of OS & $32.1 \mathrm{~m}$ & $7.4-46.5$ & $32.3 \mathrm{~m}$ & $14.9-49.1$ & $31.1 \mathrm{~m}$ & $13.9-48.1$ & 0.590 \\
\hline \multicolumn{8}{|c|}{ Without resection } \\
\hline 3-year survival & $7.5 \%$ & $0-28.6$ & $20 \%$ & $5.6-37.4$ & $0 \%$ & & 0.473 \\
\hline 5-year survival & $5.3 \%$ & $0-15.3$ & $10 \%$ & $0-22.1$ & $0 \%$ & & 1.000 \\
\hline Median of OS & $15.9 \mathrm{~m}$ & $13.9-19.1$ & $16.1 \mathrm{~m}$ & $14.3-21.1$ & $12.8 \mathrm{~m}$ & $9.7-17.2$ & 0.809 \\
\hline \multicolumn{8}{|c|}{ With resection } \\
\hline 3-year survival & $56.8 \%$ & $39.5-78.1$ & $47.6 \%$ & $32.5-83.7$ & $63.1 \%$ & $42.2-81.2$ & 0.922 \\
\hline 5-year survival & $49.5 \%$ & $34.2-64.6$ & $42.9 \%$ & $23.2-64.2$ & $53.1 \%$ & $26.7-70.2$ & 0.227 \\
\hline Median of OS & $61.2 \mathrm{~m}$ & $42.3-79.7$ & $49.2 \mathrm{~m}$ & $25.1-72.8$ & $61.7 \mathrm{~m}$ & $20.2-103.8$ & 0.568 \\
\hline DFS from resection & $57.3 \mathrm{~m}$ & $29.5-84.4$ & $37.2 \mathrm{~m}$ & $1.0-73.0$ & $61.8 \mathrm{~m}$ & $12.3-79.2$ & 0.409 \\
\hline
\end{tabular}

Vin: vinorelbine; CBDCA: carboplatin; Pac: paclitaxel.

Table 5. Chemoresistance of Tumor Cells after Neoadjuvant Chemotherapy

\begin{tabular}{|l|c|c|}
\hline Drug & No. of tests & Chemoresistance (\%) \\
\hline Cisplatin & 21 & $7(33.3 \%)$ \\
\hline Vinorelbine & 20 & $13(65.0 \%)$ \\
\hline Paclitaxel & 27 & $18(66.7 \%)$ \\
\hline Carboplatin & 29 & $23(79.3 \%)$ \\
\hline Docetaxel & 10 & $8(80.0 \%)$ \\
\hline Gemcitabine & 7 & $6(85.7 \%)$ \\
\hline Etoposide & 15 & $13(86.7 \%)$ \\
\hline
\end{tabular}

in 14 patients, with gemcitabine in 11 patients, with docetaxel in 6 patients, with paclitaxel in 5 patients and with etoposide in 3 patients. Non-platinum regimens were used in 6 patients. The planned three cycles of doublets were completed in 39 patients $(90.1 \%)$. Cycles were postponed in 39 cases $(30.2 \%)$ and dose reduction was necessary in 2 cycles (1.5\%). Anorexia (grade 3 in $11.6 \%$ ) and neutropenia (grade 4 in $7 \%$ ) were the most frequent causes of toxicity.

Harvesting of tumor cells for MTT assay was possible in 38 patients. The results of the MTT assay for chemoresistance are summarized in Table 5. The MTT assay was able to drive the choice of optimally effective drugs in 19 patients (44.2\%). However, MTT assays were not possible in 24 patients $(65.8 \%$ ) due to lack of vital tumor cells or because the cultivated tumor cells were resistant to all drugs tested. Baseline characteristics for patient subgroups, whether treated or not treated with effective drugs according to the results of MTT assay, did not differ significantly for sex, histology of tumor, type of surgery or administered chemotherapeutic regimens. Patients treated with optimally effective drugs survived longer, but the difference did not reach statistical significance (Fig. 2 and Table 6). Survival was not influenced by individual cytotoxic drugs used in adjuvant chemotherapy without respect to MTT assay (all $\mathrm{p}$ values $>0.05$ ).

\section{DISCUSSION}

The present study analyzes experience with neoadjuvant and adjuvant chemotherapies in IIIA stage NSCLC. Complete resection was realized in $67.7 \%$ patients and favorable survival was achieved, with a median of OS of 32.1 months. The three-year survival was $47.0 \%$ and the 5 -year survival $35.7 \%$. The effectiveness of the carboplatin-based neoadjuvant chemotherapy used in our centre was comparable with cisplatin regimens published in other studies. In phase III studies of cisplatin and older cytostatic drugs, radical resection rates were from $64 \%$ to $74 \%$ (ref..$^{6,7,19,26}$ ). In two studies with comparable 
Table 6. Subgroups Treated or Not Treated According to MTT Assay Results

\begin{tabular}{|c|c|c|c|}
\hline Variables & MTT utilized (\%) & MTT not utilized (\%) & $\mathrm{p}$ Value \\
\hline Men & $15(78.9)$ & $20(85.0)$ & 0.681 \\
\hline Women & $4(21.1)$ & $4(15.0)$ & \\
\hline \multicolumn{4}{|l|}{ Stage } \\
\hline $\mathrm{T} 2 \mathrm{~N} 2 \mathrm{M} 0$ & $13(68.4)$ & $18(78.2)$ & 0.278 \\
\hline T3N1M0 & $2(10.5)$ & 0 & \\
\hline T3N2M0 & $4(21.1)$ & $5(21.8)$ & \\
\hline \multicolumn{4}{|l|}{ Histology } \\
\hline Squamous cell & $14(73.7)$ & $16(69.6)$ & 0.809 \\
\hline Adenocarcninoma & $3(15.8)$ & $3(13.1)$ & \\
\hline Large cell & $2(10.5)$ & $4(17.4)$ & \\
\hline \multicolumn{4}{|c|}{ Neoadjuvant chemotherapy } \\
\hline With vinorelbine & $7(36.8)$ & $11(47.8)$ & 0.474 \\
\hline With paclitaxel & $12(63.2)$ & $12(52.2)$ & \\
\hline \multicolumn{4}{|l|}{ Surgery } \\
\hline Pneumonectomy & $9(47.4)$ & $10(43.5)$ & 0.871 \\
\hline Bilobectomy & $4(21.1)$ & $4(17.4)$ & \\
\hline Lobectomy & $6(31.5)$ & $9(39.1)$ & \\
\hline \multicolumn{4}{|l|}{ Adjuvant chemotherapy } \\
\hline With cisplatin & $10(52.7)$ & $7(30.4)$ & 0.338 \\
\hline With carboplatin & $6(31.5)$ & $10(43.4)$ & \\
\hline Other & $3(15.8)$ & $6(26.2)$ & \\
\hline \multicolumn{4}{|l|}{ Survival parameters } \\
\hline Median OS (months) & 85.1 (95\% CI 15.3-148.1) & 45.0 (95\% CI 9.1- 80.8) & 0.718 \\
\hline 3-year rate survival (\%) & $62.7(95 \%$ CI $40.7-84.7)$ & $56.4(95 \%$ CI $35.6-77.0)$ & 0.788 \\
\hline 5-year rate survival (\%) & $57.0(95 \%$ CI $34.5-79.5)$ & $43.5(95 \%$ CI $21.2-65.8)$ & 0.652 \\
\hline
\end{tabular}

long-term follow-up, median OS was 22 and 21 months, respectively, and the 5-year survival rates of $17 \%$ and $36 \%$, respectively, were recorded ${ }^{6,7}$. Cisplatin with the third generation cytotoxic agents in phase II studies show overall response rates (ORRs) from $54 \%$ to $74 \%$, but only a small number of these studies have calculated the 3-year survival ${ }^{18,27,28}$, which was $33 \%$ with a docetaxel/ cisplatin neoadjuvant protoco ${ }^{13}$ and $20 \%$ in a gemcitabine/cisplatin study ${ }^{27}$.

Vinorelbine in neoadjuvant treatment has been used in combination only with cisplatin ${ }^{29}$, or with cisplatin and gemcitabine ${ }^{30}$ and ORRs were $53.6 \%$ and $58.5 \%$, respectively. A combination of vinorelbine/carboplatin neoadjuvant regimen with radiotherapy achieved an ORR of $70 \%$ and a complete resection rate of $87 \%$ (ref. ${ }^{31}$ ). Non-platinum neoadjuvant regimen vinorelbine/gemcitabine was used in a Phase II study in different stages of NSCLC (ref. ${ }^{32}$ ). The regimen had low toxicity and $65 \%$ patients with stage IIIA underwent a complete resection.
Paclitaxel/carboplatin regimen was used in stage IIIA NSCLC in an EORTC Phase II study, ORR was $63 \%$ and the calculated median of OS was 20.5 months $^{33}$. In several other studies, no positive effect of neoadjuvant treatment was found ${ }^{10-12,34}$ but, despite all differing results a recent metaanalysis of neoadjuvant therapy in patients with resectable disease showed a hazard ratio HR 0.66 (95\% CI $0.48-0.93$ ) in favor of adding neoadjuvant chemotherapy to the standard procedure ${ }^{35}$.

The effectiveness of adjuvant chemotherapy was confirmed in several large studies, with vinorelbine and cisplatin used most often in the evaluated patients ${ }^{8,9,36}$. In the ANITA trial, the subgroup of patients with stage IIIA NSCLC achieved a median OS of 38.6 months and a 5-year survival of $42 \%$ after complete resection and adjuvant chemotherapy ${ }^{8}$. These parameters can be compared with our series of patients, who after resection and combination of adjuvant and neoadjuvant chemotherapy, achieved a median of OS 61.2 months and a 5-year survival rate $49.5 \%$. 
The present study also confirmed a very good tolerability profile, which enabled the administration of planned chemotherapy for the great majority of patients and there was no need to interrupt neoadjuvant therapy, delay or modify surgery due to toxicity, unlike a previous study which reported induction chemotherapy increases perioperative complications ${ }^{37}$.

Several studies on the neoadjuvant or adjuvant approach in IIIA NSCLC have produced comparable results to our own. It appears that the survival plateau of classic chemotherapeutic regimens without predictive markers has been reached and our results imply that multi- and cross-resistance is the major problem. Although the MTT assay has a number of technical problems with harvesting and processing of cells and reflects the behavior of tumor cells under laboratory conditions, it may provide helpful predictive and prognostic information ${ }^{38,39}$. In our study, the relative improvement in the 5-year survival was $13.5 \%$ for those treated with MTT-driven adjuvant therapy. Despite the fact that the series was small and the differences were not significant, this trend supports the concept that customized adjuvant chemotherapy may improve the survival of some patients with stage IIIA NSCLC. Future larger prospective randomized multi-institutional trials are needed to provide objective information about the MTT assay, which can be combined with other predictive or prognostic markers, such as genetic factors (KRAS, P53, RRM1, ERCC, EGFR) (ref. ${ }^{40-42}$ ). The selection of biological agents targeting specific intracellular pathways related to the distinctive properties of lung cancer cells are another promising option for optimizing adjuvant chemotherapy $^{43}$.

In conclusion, a combination of neoadjuvant and adjuvant chemotherapy in stage IIIA NSCLC is a feasible option for effective treatment giving a reasonable prognosis for patients with a good performance status. Carboplatin in combination with vinorelbine or paclitaxel as the induction treatment had an acceptable efficacy with good tolerability and low toxicity. Patients can benefit from a rational selection of drugs in the adjuvant setting, which remains one of the key problems for the future multimodal therapy of resectable IIIA NSCLC, and the MTT assay looks promising in this regard.

\section{CONFLICT OF INTEREST STATEMENT}

The authors declare that there are no conflicts of interest.

\section{ACKNOWLEDGMENTS}

Study was supported by research grants MSM 6198959216 and IGA NS 9959-3 from the Ministry of School and Education and Ministry of Health of the Czech Republic.

We would like to thank Zdenka Langova for technical support, Anna Janostakova, Jiri Lipert and Veronika Drabkova for performing the laboratory work with the MTT assay.

\section{REFERENCES}

1. Mountain CF. Revisions in the international system for staging lung cancer. Chest 1997; 11:1710-1717.

2. Komaki R, Cox JD, Hartz AJ, Byhardt RW, Perez-Tamayo C, Clowry L, Choi H, Wilson F, Lopes da Conceicao A, Rangala N. Characteristics of long-term survivors after treatment for inoperable carcinoma of the lung. Am J Clin Oncol 1985; 8:362-370.

3. Bunn PA Jr. (1994) Future dissections in clinical research for lung cancer. Chest 1994; 106:399S-407S.

4. D’Cunha J, Corfits AL, Herndon JE, Kern JA, Kohman LJ, Patterson GA, Kratzke RA, Maddaus MA. Molecular staging of lung cancer: real-time polymerase chain reaction estimation of lymph node micrometastatic tumor cell burden in stage I non-small cell lung cancer: preliminary results of Cancer and Leukemia Group B Trial 9761. J Thorac Cardiovasc Surg 2002; 123:484-491.

5. Peck K, Sher YP, Shih JY, Roffler SR, Wu CW, Yang PC. Detection and quantitation of circulating cancer cells in the peripheral blood of lung cancer patients. Cancer Res 1998; 58:2761-2765.

6. Rosell R, Gómez-Codina J, Camps C, Maestre J, Padille J, Cantó A, Mate JL, Li S, Roig J, Olazábal A. A randomized trial comparing preoperative chemotherapy plus surgery with surgery alone in patients with non-small-cell lung cancer. N Engl J Med 1994; 330:153-158.

7. Roth JA, Atkinson EN, Fossella F, Komaki R, Bernadette Ryan M, Putnam JB Jr, Lee JS, Dhingra H, De Caro L, Chasen M, Hong WK. Long-term follow-up of patients enrolled in a randomized trial comparing perioperative chemotherapy and surgery with surgery alone in resectable stage IIIA non-small-cell-lung cancer. Lung Cancer 1998; 21:1-6.

8. Douillard JY, Rosell R, De Lena M, Carpagnano F, Ramlua R, Gonzáles-Larriba JL, Grodzki T, Pereira JR, Le Groumellec A, Lorusso V, Clary C, Torres AJ, Dahabreh J, Souquet PJ, Astudillo J, Fournel P, Artal-Cortes A, Jassem J, Koubkova L, His P, Riggi M, Hurteloup P. Adjuvant vinorelbine plus cisplatin versus observation in patients with completely resected stage IB-IIIA non-small-cell lung cancer. (Adjuvant Navelbine International Trialist Association - ANITA): a randomised trial. Lancet Oncol 2006; 7:719-727.

9. Arriagada R, Bergman B, Dunant A, Le Chevalier T, Pignon JP, Vansteenkiste J. Cisplatin-based adjuvant chemotherapy in patients with completely resected non-small-cell lung cancer. N Engl J Med 2004; 350:351-360.

10. Elias AD, Skarin AT, Leong T, Mentzer S, Strauss G, Lynch T, Shulman L, Jacobs C, Abner A, Baldini EH, Frei E, Sugarbaker DJ. Neoadjuvant therapy for surgically staged IIIA N2 non-small cell lung cancer (NSCLC). Lung Cancer 1997; 17:147-161.

11. Albain KS, Rusch VW, Crowley JJ, Rice TW, Turrisi AT 3rd, Weick JK, Lonchyna VA, Presant CA, McKenna RJ, Gandara DR. Concurrent cisplatin/etoposide plus chest radiotherapy followed by surgery for stages IIIA(N2) and IIIB non-small-cell lung cancer: mature results of Southwest Oncology Group phase II stdy 8805 . J Clin Oncol 1995; 13:1880-1885(1892).

12. Van Meerbeeck JP, Kramer GW, Van Schil PE, Legrand C, Smit EF, Schramel F, Tjan-Heijnen VC, Biesma B, Debruyne C, van Zandwijk N, Splinter TA, Giaccone G. Randomized controlled trial of resection versus radiotherapy after induction chemotherapy in stage IIIA-N2 non-small-cell lung cancer. J Natl Cancer Inst 2007; 99:442-450.

13. Betticher DC, Hsu Schmitz SF, Tötsch M, Hansen E, Joss C, von Briel C, Schmid RA, Pless M, Habicht J, Roth AD, Spiliopoulos A, Stahel R, Weder W, Stupp R, Egli F,Furrer M, Honegger H, Wernli M, Cerny T, Ris HB. Mediastinal lymph node clearance after docetaxel-cisplatin neoadjuvant chemotherapy is prognostic of survival in patients with stage IIIA pN2 non-small-cell lung cancer: a multicenter phase II trial. J Clin Oncol 2003; 21:1752-1759.

14. Andre F, Grunenwald D, Pignon JP, Dujon A, Pujol JL, Brichon PY, Brouchet L, Quoix E, Westeel V, Le Chevalier T. Survival of patients with resected N2 non-small-cell lung cancer: evidence for a subclassification and implications. J Clin Oncol 2000; 18:29812989. 
15. Bueno R, Richards WG, Swanson SJ, Jaklitsch MT, Lukanich JM, Mentzer SJ, Sugarbaker DJ. Nodal stage after induction therapy for stage IIIA lung cancer determines patient survival. Ann Thorac Surg 2000; 70:1826-1831.

16. De Leyn P, Stroobants S, De Wever W, Lerut T, Coosemans W, Decker G, Nafteux P, Van Raemdonck D, Mortelmans L, Nackaerts $\mathrm{K}$, Vansteenkiste J. et al. Prospective comparative study of integrated positron emission tomography-computed tomography scan compared with remediastinoscopy in the assessment of residual mediastinal lymph node disease after induction chemotherapy for mediastinoscopy-proven stage IIIA-N2 non-small-cell lung cancer: a Leuven Lung Cancer Group study. J Clin Oncol 2006; 24:33333339.

17. Martin J, Ginsberg RJ, Abolhoda A, Bains MS, Downey RJ, Korst RJ, Weigel TL, Kris MG, Venkatraman ES, Rusch VW. Morbidity and mortality after neoadjuvant therapy for lung cancer: the risks of right pneumonectomy. Ann Thorac Surg 2001; 72:1149-1154.

18. Voltolini L, Luzzi L, Ghiribelli C, Paladini P, Di Bisceglie M, Gotti G. Results of induction chemotherapy followed by surgical resection in patients with stage IIIA (N2) non-small cell lung cancer: the importance of the nodal down-staging after chemotherapy. Eur J Cardiothorac Surg 2001; 20:1106-1112.

19. Depierre A, Milleron B, Moro-Sibilot D, Chevret S, Quoix E, Lebeau B, Braun D, Breton JL, Lemarié E, Gouva S, Paillot N, Bréchot JM, Janicot H, Lebas FX, Terrioux P, Clavier J, Foucher P, Monchâtre M, Coëtmeur D, Level MC, Leclerc P, Blanchon F, Rodier JM, Thiberville L, Villeneuve A, Westeel V, Chastang C; French Thoracic Cooperative Group. Preoperative chemotherapy followed by surgery compared with primary surgery in resectable stage I (except T1N0), II, and IIIa non-small-cell lung cancer. J Clin Oncol 2002; 20:247-253.

20. Santomaggio C, Tucci E, Rinaldini M, Algeri R, Righi R, Pepi F, Ghezzi P, Andrei A, Bellezza A. Carboplatin and vinorelbine in the treatment of advanced non-small-cell lung cancer: a multicenter phase II study. Am J Clin Oncol 1998; 21:67-71.

21. Schiller JH, Harrington D, Belani CP, Langer C, Sandler A, Krook J, Zhu J, Johnson DH; Eastern Cooperative Oncology Broup. Comparison of four chemotherapy regimens for advanced nonsmall-cell lung cancer. N Engl J Med 2002; 346:92-98.

22. Miller AB, Hoogstraten B, Staquet M, Winkler A. Reporting results of cancer treatment. Cancer 1981; 47:207-214.

23. Hajdúch M, Mihál V, Minarík J, Faber E, Safárovă M, Weigl E, Antálek P. Decreased in vitro chemosensitivity of tumour cells in patients suffering from malignant diseases with a poor prognosis. Cytotechnology 1996; 19:243-255.

24. Kaplan EL, Meier P. Nonparametric estimation from incomplete observations. J Am Stat Assoc 1958; 53:457-481.

25. Mantel N. Evaluation of survival data and two new rank order statistics arising in its consideration. Cancer Chemother Rep 1966; 50:163-170.

26. Pass HI, Pogrebniak HW, Steinberg SM, Mulshine J, Minna J. Randomized trial of neoadjuvant therapy for lung cancer: interim analysis. Ann Thorac Surg 1992; 53:992-998.

27. Van Zandwijk N, Smit EF, Kramer GW, Schramel F, Gans S, Festen J, Termeer A, Schlosser NJ, Debruyne C, Curran D, Giaccone G. Gemcitabine and cisplatin as induction regimen for patients with biopsy-proven stage IIIA N2 non-small-cell lung cancer: a phase II study of the European Organization for Research and Treatment of Cancer Lung Cancer Cooperative Group (EORTC 08955). J Clin Oncol 2000; 18:2658-2664.

28. De Marinis F, Nelli F, Migliorino MR, Martelli O, Cortesi E, Treggiari S, Portalone L, Crispino C, Brancaccio L, Gridelli C. Gemcitabine, paclitaxel, and cisplatin as induction chemotherapy for patients with biopsy-proven stage IIIA(N2) non-small cell lung carcinoma: a phase II multicenter study. Cancer 2003; 98:17071715.

29. Cigolari S, Curcio C, Maiorino A, Sessa R, Cioffi A, Massimo M. Cisplatin plus vinorelbine as induction chemotherapy followed by surgery in the treatment of stage IIIB non-small cell lung cancer. Final results of a multicenter phase II study. Anticancer Res 2003; 23:1803-1810.
30. León L, Cueva-Banuelos JF, Huidobro G, Fírvida JL, Amenedo M, Lázaro M, Romero C, Estévez SV, Barón FJ, Grande C, García Mata J, González A, Castellanos J, Gómez A, Caeiro M, Rodríguez MR, Casal J; Galician Lung Cancer Group. Gemcitabine, cisplatin and vinorelbine as induction chemotherapy followed by radical therapy in stage III non-small-cell lung cancer: a multicentre study of galician-lung-cancer-group. Lung Cancer 2003; 40:215-220.

31. Garst J, Shafman T, D'Amico T. A phase II trial of neo-adjuvant concurrent carboplatin and vinorelbine chemotherapy with radiation followed by surgical resection in patients with stage IIB/IIIA non-small-cell lung cancer. Proc Ann Meet Am Soc Clin Oncol 2002; 21:Abst. 1268.

32. Ramnath N, Sommers E, Robinson L, Nwogu C, Sharma, Cantor A, Bepler G. Phase II study of neoadjuvant chemotherapy with gemcitabine and vinorelbine in resectable non-small cell lung cancer. Chest 2005; 128:3467-3474.

33. O'Brien ME, Splinter T, Smit EF, Biesma B, Krzakowski M, Tjan-Heijnen VC, Van Bochove A, Stigt J, Smid-Geirnaerdt MJ, Debruyne C, Legrand C, Giaccone G; EORTC Lung Cancer Group. Carboplatin and paclitaxel (Taxol) as an induction regimen for patients with biopsy-proven stage IIIA N2 non-small cell lung cancer. An EORTC phase II study (EORTC 08958). Eur J Cancer 2003; 39:1416-1422.

34. Shepherd FA, Johnston MR, Payne D, Burkes R, Deslauriers J, Cormier Y, de Bedoya LD, Ottaway J, James K, Zee B. Randomized study of chemotherapy and surgery versus radiotherapy for stage IIIA non-small-cell lung cancer: a National Cancer Institute of Canada Clinical Trial Group Study. Br J Cancer 1998; 78:683685.

35. Berghmans T, Paesmans M, Meert AP, Mascaux C, Lothaire P, Lafitte JJ, Sculier JP. Survival improvement in resectable non-smallcell lung cancer with (neo)adjuvant chemotherapy: Results of a meta-analysis of the literature. Lung Cancer 2005; 49:13-23.

36. Winton T, Livingston R, Johnson D, Rigas J, Johnston M, Butts C, Cormier Y, Goss G, Inculet R, Vallieres E, Fry W, Bethune D, Ayoub J, Ding K, Seymour L, Graham B, Tsao MS, Gandara D, Kesler K, Demmy T, Shepherd F; National Cancer Institute of Canada Clinical Trials Group; National Cancer Institute of the United States Intergroup JBR.10 Trial Investigators. Vinorelbine plus cisplatin vs. observation in resected non-small-cell lung cancer. N Engl J Med 2005; 352:2589-2597.

37. Roberts JR, Eustis C, Devore R, Carbone D, Choy H, Johnson D. Induction chemotherapy increases perioperative complications in patients undergoing resection for non-small-cell lung cancer. Ann Thorac Surg 2001; 72:885-888.

38. Campling BG, Pym J, Baker HM, Cole SP, Lam YM. Chemosensitivity testing of small cell lung cancer using the MTT assay. Br J Cancer 1991; 63:75-79.

39. Rubinstein LV, Shoemaker RH, Paull KD, Simon RM, Tosini S, Skehan P, Scudiero DA, Monks A, Boyd MR. Comparison of in vitro anticancer-drug-screening data generated with a tetrazolium assay versus a protein assay against a diverse panel of human tumour cell lines. JNCI 1990; 82:1113-1118.

40. Rosell R, Felip E, Taron M, Majo J, Mendez P, Sanchez-Ronco M, Queralt C, Sanchez JJ, Maestre J. Gene expression as a predictive marker of outcome in stage IIB-IIIA-IIIB non-small cell lung cancer after induction gemcitabine-based chemotherapy followed by resectional surgery. Clin Cancer Res 2004; 10:4215-4219.

41. Olaussen KA, Dunant A, Fouret P, Brambilla E, André F, Haddad V, Taranchon E, Filipits M, Pirker R, Popper HH, Stahel R, Sabatier L, Pignon JP, Tursz T, Le Chevalier T, Soria JC; IALT Bio Investigators. DNA repair by ERCC1 in non-small-cell lung cancer and cisplatin-based adjuvant chemotherapy. N Engl J Med 2006; 355:983-991.

42. Zheng Z, Chen T, Li X, Haura E, Sharma A, Bepler G. DNA Synthesis and repair genes RRM1 and ERCC1 in lung cancer. N Engl J Med 2007; 356:800-811.

43. Sandler A, Gray R, Perry MC, Brahmer J, Schiller JH, Dowlati A, Lilenbaum R, Johnson DH. Paclitaxcel-carboplatin alone or with bevacizumab for non-small-cell lung cancer. N Engl J Med 2006; 355:2542-2550. 